\title{
ANALISIS LOGO HARI ULANG TAHUN KOTA SEMARANG KE-469 HASIL KARYA IBNU PRAMUDYA
}

\author{
Fibriyani Nur Aliya \\ Mahasiswa Program Studi Magister Ilmu Komunikasi FISIP UNDIP Angkatan VIII \\ Email: ayik20@gmail.com
}

\begin{abstract}
The aim of the study is questioning the meaning of Semarang's $469^{\text {th }}$ birthday celebration logo. By using Semiotic Theory of Charles Sanders Peirc this research analyse the logo from the perspective of the symbols, the used of symbols, and the interpreters. The result of the study show that the logo is unique and represent unity and harmony of Semarang people. The result of the study also show that semiotic reveal similar meaning produced by the judges. The meaning of the logo also support main theme of Semarang's $469^{\text {th }}$ birthday celebration, 'Bulatkan Tekat Semarang Hebat'.
\end{abstract}

Keywords: Semiotic, logo, Semarang's $46^{\text {th }}$ birthday celebration, Charles Sanders Peirce

\section{Pendahuluan}

Logo HUT Kota Semarang ke 469adalah hasil karya Ibnu Pramudya. Ibnu merupakan pemenang Lomba Logo HUT Kota Semarang ke 469 yang digelar oleh Pemerintah Kota dalam rangkaian peringatan HUT Kota Semarang ke 469. Logo hasil karya pemuda asal Boja, Kendal ini dinilai memiliki keunikan dan daya tarik tersendiri. Logo dengan bentukan dua tali yang saling terkait menggunakan gradasi warna merah dan kuning mampu menyisihkan 377 karya peserta lainnya. Logo yang menarik ini, tidak hanya akan menjadi logo perayaan HUT Kota Semarang ke 469, tetapi juga akan menjadi logo seluruh kegiatan yang digelar oleh Pemerintah Kota Semarang dalam satu tahun.

Lomba Logo diadakan untuk peringatan HUT Kota Semarang, sama seperti tahun-tahun sebelumnya. Lomba ini dilatarbelakangi oleh keinginan Pemerintah Kota Semarang dalam melibatkan masyarakat pada setiap kegiatan yang digelar. Hal ini disampaikan oleh Achyani, Kepala Bagian Humas Pemerintah Kota Semarang. Achyani mengatakan, dengan mengusung tema
"Bulatkan Tekad, Semarang Hebat", melalui HUT Kota Semarang tahun ini diharapkan seluruh lapisan masyarakat, bisa ikut memeriahkan seluruh rangkaian kegiatan serta memiliki kebanggaan terhadap kotanya sendiri (Suaramerdeka.com, 28 Maret 2016).

Keluarnya logo hasil karya Ibnu Pramudya sebagai pemenang lomba merupakan hasil penilaian para dewan juri. Juri Utama yang merupakan Walikota Semarang, Hendrar Prihadi mengakui, logo karya Ibnu memang cukup menonjol. Jalinan angka 4, 6 dan 9 dapat menunjukkan semangat bekerja demi mewujudkan Semarang hebat. "Ini sangat cocok dengan tema HUT tahun ini yakni 'Bulatkan Tekad Semarang Hebat', dimana memang sumbangan dari masyarakat salah satunya hasil Lomba Logo ini, memang sangat kami nantikan. Jadi pemerintah tidak bekerja sendiri dalam hal ini," tuturnya (Tabloidsimpang5.com, 31 Maret 2016).

Logo milik Ibnu Pramudya dinilai mampu menjawab syarat yang diberikan oleh panitia dan dewan juri. Ketua Panitia Lomba Logo HUT 
Semarang, Tutuk Carita mengatakan, keberadaan sebuah logo HUT diharapkan mampu menjadi ikon, simbol, dan perlambang semangat dalam membangun kota. Seperti pada tahun-tahun sebelumnya, tahun ini dinilai juga perlu dibuat sebuah logo yang melambangkan karakter, visi-misi, semangat dan kekuatan kebersamaan dalam membangun kota. "Diharapkan dengan keberadaan logo ini, akan mampu menjadi wadah untuk penampung aspirasi masyarakat. Selain itu juga sebagai bentuk pelibatan masyarakat dalam proses pembangunan," imbuhnya (Beritajateng. net, 18 Maret 2016).

Napoles (1998: 13) mengungkapkan bahwa identitas visual mampu memberi wajah dan kepribadian dalam bentuk sebuah logo. Hal ini dapat diaplikasikan pada sebuah organisasi, perusahaan, kota, provinsi, bahkan negara. Pada studi ini, logo karya Ibnu Pramudya, identitas visual diaplikasikan pada sebuah kota. Kota tanpa 'wajah' tidak akan dikenali oleh masyarakatnya terlebih oleh masyarakat luar secara luas. Hal ini yang menjadi dasar bahwa makna sebuah logo harus menjadi perhatian dalam strategi kreatif penciptaan logo itu sendiri, baik untuk perusahaan maupun kota. Hal tersebut dikarenakan logo merupakan atribut utama yang dilihat secara fisik. Melalui logo tersirat kepribadian sebuah perusahaan maupun identitas sebuah kota seperti, visi dan misi, budaya, nilai dan seluruh kepribadian lainnya yang tersirat secara non fisik dalam logo.

Berdasar pada konsep yang disampaikan oleh Napoles, logo dapat diartikan sebagai jati diri, wajah, dan lambang identitas. Logo juga dilihat sebagai alat komunikasi kepada pihak luar tentang identitas dan pesan yang ingin disampaikan kepada khalayak. Maraknya penggunaan logo pada sebuah organisasi, perusahaan, kota, provinsi, dan negara menjadikan studi mengenai pemahaman logo penting untuk dipelajari. Selain ilmu yang mengkaji mengenai pembuatan logo, diperlukan juga ilmumengenai metode analisis logo itu sendiri.
Ilmu analisis logo perlu dipelajari guna memahami pesan yang ingin disampaikan melalui logo tersebut. Interpretasi terhadap logo akan memiliki pengertian yang tidak terbatas dan hal ini akan menjadi rancu, apabila ilmu mengenai analisis logo tidak diterapkan.

Ilmu yang sudah sangat dikenal sebagai metode guna menganalisis tanda adalah semiotika (Sobur, 2013: 11). Sobur juga mengungkapkan bahwa semiotika dipandang sebagai bidang studi tentang tanda dan cara tanda-tanda itu bekerja, di mana dikatakan juga sebagai semiologi. Tanda merupakan sesuatu yang bersifat fisik, bisa dipersepsi indra kita, tanda mengacu pada sesuatu di luar tanda itu sendiri, dan bergantung pada pengenalan oleh penggunanya sehingga disebut tanda.

Berdasar pada pengertian semiotika yang dilihat sebagai ilmu tentang metode analisis tanda dan pengertian tanda yang diungkap Sobur, dapat ditarik kesimpulan bahwa studi mengenai analisis tanda menggunakan metode semiotika penting guna kemajuan ilmu komunikasi yang mengkaji tentang komunikasi non verbal pada umumnya dan kaitannya dengan tanda pada khususnya. Salah satu opsi penggunaan metode riset desain yang substainsional adalah semiotika dan opsi ini dinilai sangat menarik.

Studi tentang semiotika menjadi penting karena semiotika adalah pendekatan yang absah, yang di dalamnya sesuatu menyerupai sesuatu yang lain. Dalam semiotika, objek-objek kerangka referensi di dunia desain biasanya menjadi objek-objek konseptual, yang materialisme hanya bertindak sebagai wahana tanda.Dengan berfokus pada sistem-sistem semiotika, diharapkan dapat mempelajari fenomena tertentu dalam dunia desain, seperti representasi, retorika, dan penilaian terhadap objek-objek (Vakeva, 2009: 137).

Semiotika dikategorikan menjadi empat, hal ini dikemukakan oleh Eero Tarasti (Vakeva, 2009: 128), yaitu: 
1. Semiotika filosofi: John Luke, Charles Sanders Peirce.

2. Semiotika empiris: ilmu kedokteran Yunani, Thure von Pexkull

3. Semiotika linguistik: Ferdinand de Saussure, aliran semiotika Perancis (A. J. Greimas).

4. Semiotika budaya: Yuri Lotman (aliaran semiotika Tartu-Moskow).

Beberapa aliran semiotika tersebut menggunakan struktur dan terminologi berbeda dalam pemikiran masing-masing. Charles Sanders Pierce mendefinisikan tanda sebagai kesatuan triadik, sementara Ferdinand de Saussure mengandalkan dikotomi, dan Algirdaus Julien Greimas tidak membutuhkan konsep tanda sama sekali (Vakeva, 2009: 128).

Dari beberapa tokoh semiotika, tokoh yang memusatkan perhatiannya pada studi semiotika tanda adalah Charles Sanders Peirce. Peirce terkenal karena teori tandanya. Peirce seringkali mengulang-ulang bahwa secara umum tanda adalah yang mewakili sesuatu bagi seseorang, namun perumusan ini dinilai terlalu sederhana karena menyalahi kenyataan tentang adanya suatu fungsi tanda: tanda Amenunjukkan suatu fakta (atau objek B), kepada penafsirnya, yaitu C. Berdasarkan hal itu, tanda dipandang sebagai suatu entitas yang tidak sendirian, tetapi memiliki ketiga aspek tersebut (Lechte (2001) dalam Sobur, 2013: 41).

Lebih jelasnya Peirce mengatakan bahwa tanda itu sendiri merupakan contoh dari Kepertamaan, objeknya adalah Kekeduaan, dan penafsirnya-unsur pengantara-adalah contoh dari Keketigaan (Sobur, 2013: 41). Hal ini dapat diartikan bahwa suatu tanda merupakan perwakilan dari suatu objek dan membutuhkan penafsir untuk memaknai tanda dari objek tersebut. Ketiga elemen ini tidak dapat dipisahkan dalam menganalisis sebuah tanda.

Sobur (2013: 41) juga menjelaskan bahwa Keketigaan yang ada dalam konteks pembentukan tanda membangkitkan semiotika yang tidak terbatas, di mana satu penafsir yang membaca tanda sebagai tanda bagi yang lain (yaitu sebagai wakil dari suatu makna atau penanda) bisa ditangkap oleh penafsir yang lain . Penafsir adalah unsur yang harus ada dan penting untuk mengaitkan tanda dengan objeknya (induksi, deduksi, dan penangkapan membentuk tiga jenis penafsir yang penting). Dapat dikatakan bahwa yang disebut penafsir bukan hanya yang melihat tanda tersebut, pembuat tanda juga dapat disebut sebagai penafsir. Hal ini berkaitan dengan kemampuan pencipta dalam membuat sebuah tanda yang mewakili suatu objek dan dapat dimaknai sama oleh penafsir yang lain.

Berdasar pada uraian latar belakang di atas, studi ini berfokus pada bagaimana logo HUT Kota Semarang ke-469, hasil karya Ibnu Pramudya mampu mengkomunikasikan visi dan misi serta kepribadian Kota Semarang di hari jadinya yang ke 469 tahun. Pemaknaan logo akandilihat menggunakan semiotikasegitiga makna Charles Sanders Peirce yang telah dikemukakan sebelumnya mengenai tanda, objek, dan penafsir. Melalui semiotika diharapkan logo yang diciptakan oleh Ibnu mampu dipahami sebagai tanda yang mewakili identitas Kota Semarang dan dimaknai sama oleh orang lain yang melihat tanda ini.

\section{KAJIAN TEORITIK}

\section{Teori Komunikasi}

Premis semiotika tanda sangat sejalan dengan teori komunikasi modern. Dari sudut pandang desain, teori ini difokuskan pada proses yang melaluinya desainer mentransmisikan pesan kepada pengguna dengan menggunakan produk itu sendiri sebagai piranti transmisi. Hal ini merupakan representasu mode komunikasi dasar: pesan diciptakan, ditransmisikan, diterima dan ditanggapi (Vakeva, 2009: 17).

Menurut Craig (Littlejohn, 2009: 8) teori harus dipandang sebagai sebuah pernyataan atau argumen berdasarkan pendekatannya daripada 
hanya melihatnya sebagai sebuah penjelasan dari sebuah proses. Craig memandang komunikasi tidak akan menyatu dengan sebuah teori tunggal atau kelompok teori. Hal ini berdasar pada pandangan Craig bahwa komunikasi sebagai proses utama di mana kehidupan manusia dijalani: komunikasi mendasari kenyataan.

Pendapat Craig sejalan dengan pandangan Littlejohn (2009: 502), di mana Littlejohn memandang teori komunikasi sebagai satu teori atau sekumpulan pemikiran yang didapati pada keseluruhan teori terutamanya yang berkaitan dengan proses komunikasi.

Berdasar pada pemahaman teori komunikasi yang diungkap oleh beberapa ahli, vakave dalam bukunya Semiotika Visual dan Semantikam Produk menyimpulkan empat komponen pokok teori komunikasi: a) pesan, tanda, atau kode, b) keluaran (output) atau transmisi, c) masukan (input) atau resepsi, dan d) tanggapan (Chambers (1985), dalam Vakave, 2009: 18).

\section{Komunikasi Visual}

Komunikasi visual adalah teori yang mengkaji tentang komunikasi dan ungkapan kreatif, teknik dan media untuk menyampaikan pesan, arahan dan sebagainya secara visual, termasuk audio dengan mengolah elemen grafik seperti bentuk dan gambar, huruf dan warna, serta tata letaknya, sehingga pesan dapat diterima. Komunikasi visual berkaitan dengan penggunaan simbol, tanda-tanda (signs), gambar, lambang, ilmu dalam penulisan huruf(tipografi), ilustrasi, dan warna yang kesemuanya berkaitan dengan pancaindera penglihatan. Contoh bentuk-bentuk komunikasi visual diantaranya poster, simbol, warna, logo, maskot, tipografi, pengemasan, dan lain-lain (Razhiza, 2009).

Razhiza (2009) menerangkan, komunikasi visual selain menggunakan teks juga melalui eksplorasi ide-ide dengan penambahan foto, diagram, pemilihan warna dan pedukung lainnya sehinga menghasilkan kesan bagi yang melihat dan pesan yang ingin disampaikan mampu dipahami. Namun kesan yang dihasilkan bergantung pada tujuan yang ingin disampaikan oleh pengirim pesan dan juga kemampuan penerima untuk memproses pesan tersebut. Pada prinsipnya pesan visual yang ingin disampaikan harus kreatif(asli, menarik, dan mudah dipahami), komunikatif, efisian, dan efektif sekaligus memiliki nilai estetika.

Dapat disimpulkan bahwa komunikasi visual adalah proses penyampaian pesan melalui lambang yang dapat diterima hanya melalui indra penglihatan. Komunikasi visual dapat bersifat langsung (bahasa isyarat) atau melalui media komunikasi visual seperti yang telah dicontohkan di atas.

\section{Desain Komunikasi Visual}

Tinarbuko (2009: 23) mengutip pengertian desain komunikasivisual dari beberapa tokoh diantaranya; Widagdo yang mendefinisikan desain komunikasi visual dalam pengertian modern adalah desain yang dihasilkan dari rasionalitas, dilandasi pengetahuan, bersifat rasional, dan pragmatis.T. Sutanto menyatakan bahwa desain komunikasi visual senantiasa berhubungan dengan penampilan rupa yang dapat dicerap orang banyak dengan pikiran maupun perasaan.Rupa yang mengandung pengertian atau makna, karakter, serta suasana yang mampu dipahami (diraba dan dirasakan) oleh khalayak umum atau terbatas. Sedangkan dalam pandangan Sanyoto, desain komunikasi visual memiliki pengertian secara menyeluruh, yaitu rancangan sarana komunikasi yang bersifat kasat mata.

Tinarbuko (2009: 24) memberikan pengertian desain komunikasi visual sebagai ilmu yang mempelajari konsep dan ungkapan daya kreatif, yang diaplikasikan dalam pelbagai media komunikasi visuak dengan mengolah elemen desain grafis yang terdiri atas gambar (ilustrasi), huruf, dan tipografi, warna, komposisi, dan layout. Semua itu dilakukan guna menyampaikan 
pesan secara visual, audio, dan atau audio visual kepada target sasaran yang dituju.

\section{Tipografi}

Tipografi diperlakukan sebagai kurir komunikasi visual. Dalam hal ini tipografi dalam lambang bunyi yang divisualisasikan melalui bentuk simbol-simbol yang disusun sedemikian rupa sehingga dapat dibaca dan dimengerti maksudnya. Dalam peradaban mpdern, lambang bunyi yang berbentuk huruf memiliki peranan penting dalam sebuah proses komunikasi antar manusia. Huruf dan tipografi menjadi ujung tombak guna menyampaikan pesan verbal dan pesan visual kepada seseorang, sekumpulan orang, bahkan masyarakat luas yang dijadikan tujuan akhir proses penyampaian pesan dari komunikator kepada komunikan atau target sasaran (Tinarbuko, 2009: 24).

Tiopografi adalah seni memilih dan menata huruf untuk pelbagai kepentingan menyampaikan informasi berbentuk pesan sosial atau komersial. Tipografi fipandang dalam komunikasi visual mencakup pemilihan bentuk huruf, besar huruf, cara dan teknik penyusunan huruf menjadi kata atau kalimat sesuai dengan karakter pesan (sosial atau komersial) yang ingin disampaikan (Tinarbuko, 2009: 25).

\section{Logo}

Menurut Sobur (2004:120) logo sebagai identitas diri, logo sebagai “jiwa", logo sebagai "pakaian", logo memiliki banyak peran penting dalam pembentukan citra dan persepsi khalayak banyak. Logo sebagai nama suatu perusahaan yang baru dalam perkembangannya menggunakan logo sebagai interaksinya dengan lingkungan, ada beberapa alasan suatu perusahaan benar-benar merencanakan dengan sangat baik bentuk logo bagi perusahaannya.

Logo juga diartikan sebagai suatu bentuk gambar atau sekedar sketsa dengan arti tertentu dan mewakili suatu arti dari perusahaan, daerah, perkumpulan, produk, negara dan hal-hal lainnya yang dianggap membutuhkan hal yang singkat dan mudah diingat sebagai ganti dari nama sebenarnya (Adi, 2009: 2).

Sedangkan John Murphy dan Michael Rowe (Suwardikun, 2000: 7) berpendapat bahwa setiap produk atau organisasi yang sukses, memiliki sendiri kepribadiannya dan kepribadian manusia yang kompleks, demikian juga kepribadian produk dan organisasi. Trademark dan logo dari produk dan organisasi adalah penampilan dari penyingkatan kenyataan yang kompleks ke dalam suatu pernyataan yang sederhana, sesuatu yang bisa dikontrol, dimodifikasi, dikembangkan dan dimatangkan setiap saat.

\section{Logo Sebagai Alat Komunikasi}

Tanda-tanda (signs) adalah basis dari seluruh komunikasi (Littlejohn dalam Sobur, 2013: 15). Manusia dengan perantaraan tandatanda, dapat melakukan komunikasi dengan sesamanya. Banyak hal bisa dikomunikasikan di dunia ini (Sobur, 2013: 15).

Manusia adalah makhluk yang berbahasa, manusia dengan perantaraan tanda-tanda dapat melakukan komunikasi dengan sesamanya. Manusia berkomunikasi dengan cara verbal dan non verbal. A.H Baker (Sobur, 2003: 140) menjelaskan beberapa ungkapan sebagai berikut: Pertama, manusia hanya sadar dalam bahasa, angan-angan yang memakai fantasi dan konsepkonsep. Komunikasi simbolis mengandalkan kesadaran mendalam dan karena itu menuntut penyertaan bahasa. kedua, bahasa simbolis menciptakan situasi yang simbolis juga. Artinya, penuh dengan tanda tanya atau hal-hal yang mesti diungkapkan maksud dan arti yang terkandung didalamnya. Ketiga, Bahasa simbolis terletak ditengah antara bahasa mistis dan alegoris seperti halnya pula berlaku dalam tindakan.

Suatu tanda, atau representamen, merupakan sesuatu yang menggantikan sesuatu 
bagi seseorang dalam beberapa hal atau kapasitas. Ia tertuju kepada seseorang, artinya di dalam benak orang itu tercipta suatu tanda lain yang akuivalen, atau mungkin suatu tanda yang lebih berkembang. Tanda menggantikan sesuatu, yaitu objeknya, tidak dalam segal hal, melainkan dalam rujukannya pada sejumput gagasan, yang kadang disebut sebagai latar dari representamen (Peirce dalam Budiman, 2011: 73)

Berdasarkan pengertian-pengertian logo yang telah disampaikan sebelumnya, dan pendapat-pendapat para ahli mengenai tanda sebagi alat pengganti objek atau pesan, dapat disimpulkan bahwa logo yang merupakan salahsatu bagian dari tanda adalah pengganti objek dan representamen dari pesan yang ingin disampaikan oleh objek tersebut.

\section{Semiotika}

Teori Semiotika dimengerti sebagai suatu ilmu atau metode analisis untuk mengkaji tanda. Tanda-tanda adalah perangkat yang kita pakai dalam upaya berusaha mencari jalan di dunia ini, di tengah-tengah manusia dan bersama-sama manusia. Semiotika sebagai bidang studi tentang tanda dan cara tanda-tanda itu bekerja dikatakan juga semiologi. Dalam memahami studi tentang makna terdapat tiga unsur utama diantaranya: (1) tanda, (2) acuan tanda, dan (3) pengguna tanda. Tanda merupakan sesuatu yang bersifat fisik, bisa dipersepsi indra kita, tanda mengacu pada sesuatu di luar tanda itu sendiri, dan bergantung pada pengenalan oleh penggunanya sehingga disebut tanda (Sobur, 2013: 11).

Semiotika, yang biasanya didefinisikan sebagai pengkajian tanda-tanda (thestudy of signs), pada dasarnya merupakan sebuah studi atas kode-kode, yaitu sistem apa pun yang memungkinkan kita memandang entitas-entitas tertentu sebagai tanda-tanda atau sebagai sesuatu yang bermakna (Scholes dalam Budiman, 2011: 3).

\section{Semiotika Komunikasi Visual}

Seperti telah dijelaskan sebelumnya mengenai semiotika dan design komunikasi visual bahwa semiotika merupakan ilmu yang mempelajari tentang tanda, berfungsinya tanda, dan produksi makna. Tanda adalah sesuatu yang bagi seseorang berarti sesuatu yang lain (Tinarbuko, 2009: 17). Sedangkan design komunikasi visual adalah ilmu yang mempelajari konsep dan ungkapan daya kreatif, yang diaplikasikan dalam pelbagai media komunikasi visuak dengan mengolah elemen desain grafis yang terdiri atas gambar(ilustrasi), huruf, dan tipografi, warna, komposisi, dan lay-out. Semua itu dilakukan guna menyampaikan pesan secara visual, audio, dan atau audio visual kepada target sasaran yang dituju (Tinarbuko, 2009: 24).

Dapat diambil kesimpulan, semiotika komunikasi visual adalah upaya memberikan sebuah pandangan terhadap semiotika sebagi ilmu. Semiotika digunakan sebagai sebuah metode untuk membaca hasil karya desain komunikasi visual.

\section{Metode Penelitian}

Jenis studi ini adalah studi kualitatif dengan menggunakan paradigma kritis. Metode yang digunakan adalah metode semiotika Charles Sanders Peirce . Peirce membuat model sistematis dalam menganalisis makna dengan tanda-tanda: 


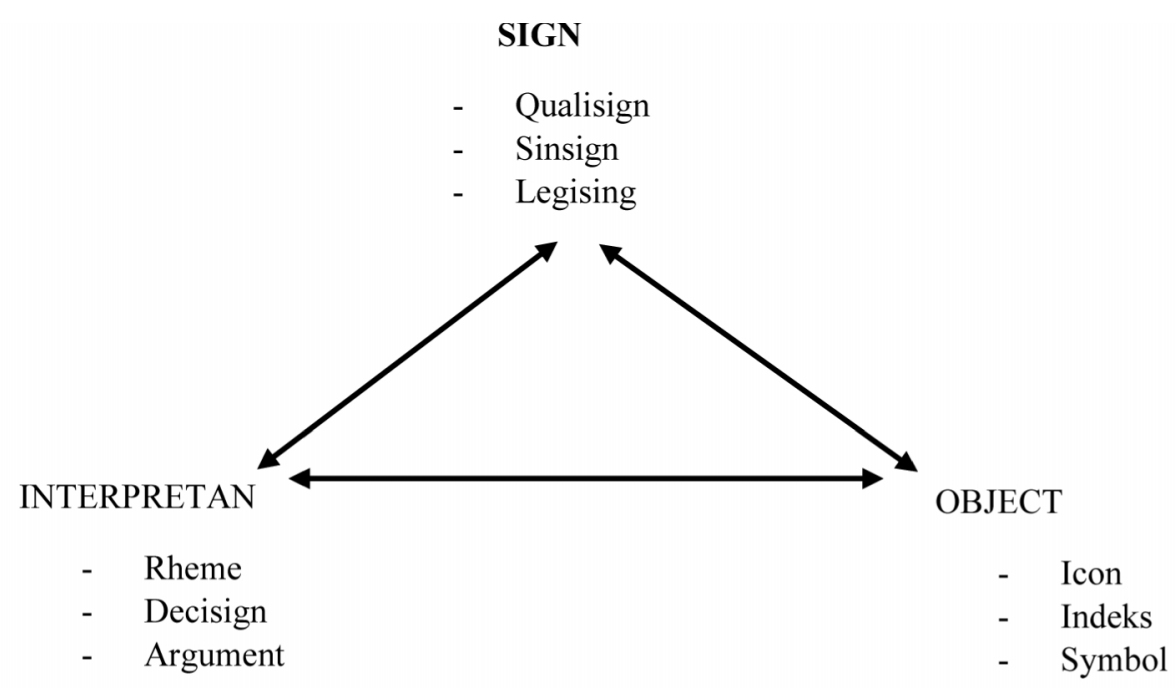

(Sumber: Diah Lukita Sari, 2011. Analisis Semiotika Logo Ades.)

Fokus perhatiannya tertuju pada segitiga makna (triangle meaning) di mana Peirce mengungkapkan bahwa salah satu bentuk tanda adalah kata. Sedangkan objek adalah sesuatu yang dirujuk tanda. Di sisi lain interpretan adalah tanda yang ada dalam benak seseorang tentang objek yang dirujuk sebuah tanda. Proses interaksi ketiga elemen makna tersebut dalam benak interpretan akan memunculkan makna yang diwakili oleh sebuah tanda tersebut (Sobur, 2009: 12).

\section{Hasil Penelitian}

Seperti pada tahun sebelumnya, pengadaan Lomba Logo HUT Kota Semarang ke 469 diumumkan melalui akun facebook Pemerintah Kota Semarang dan dipublikasikan oleh media-media massa lokal. Para panitia dan juri juga mengumumkan lomba bergengsi ini melalui akun-akun pribadinya.

Kriteria Lomba Logo HUT Kota Semarang ke 469 adalah sebagai berikut:
1. Inovatif, sederhana, dan mudah diingat

2. Karya asli/tidak plagiat

3. Tidak mengandung unsur SARA

4. Logo tidak pernah dipublikasikan sebelumnya

5. Logo mencerminkan visi misi, sejarah, unsur kekinian karakter, semangat pembangunan kota

6. Logo dapat diaplikasikan diseluruh media

7. Logo bertuliskan 469

Selain beberapa kriteria di atas, Lomba Logo HUT Kota Semarang ke 469 juga mencantumkan beberapa syarat umum seperti halnya kewarganegaraan Indonesia, peserta dapat berbentuk perorangan maupun organisasi, setiap peserta hanya diperbolehkan mengirimkan dua desain logo, dan mencantumkan data diri lengkap.

Teknis penilaian dan pengumuman pemenang disertakan juga dalam publikasi pengadaan lomba. Pada tahap awal seleksi akan dipilih lima puluh besar logo terbaik, tahap selanjutnya dari kelimapuluh karya tersebut 
diseleksi kembali menjadi dua puluh besar. Seleksi selanjutnya disaring menjadi lima besar. Seluruh tahapan seleksi tersebut dilakukan oleh para dewan juri yang terdiri dari ketua DPRD Kota Semarang Supriyadi, praktisi desain Adam Muda dan Ketua Forum Wartawan Kota (Forwakot) Lanang Wibisono.Kelima besar karya terbaik kemudian diajukan kepada walikota Semarang, Hendrar Prihadi, untuk dipilih satu sebagai pemenang.
Pada beberapa media lokal, ketua panitia Lomba Logo Hari Ulang Tahun (HUT) Kota Semarang yang ke 469 , telah mengumumkan karya Ibnu Pramudya sebagai pemenang. Karya pemuda asal Kendal ini secara langsung dipilih oleh Walikota Semarang, Hendrar Prihadi, setelah melalui serangkaian proses seleksi. Selanjutnya karya Ibnu secara resmi akan digunakan dalam setiap acara dan kegiatan yang diselenggarakan pemerintah Kota Semarang.

\section{Logo HUT Semarang karya Ibnu Pramudya}

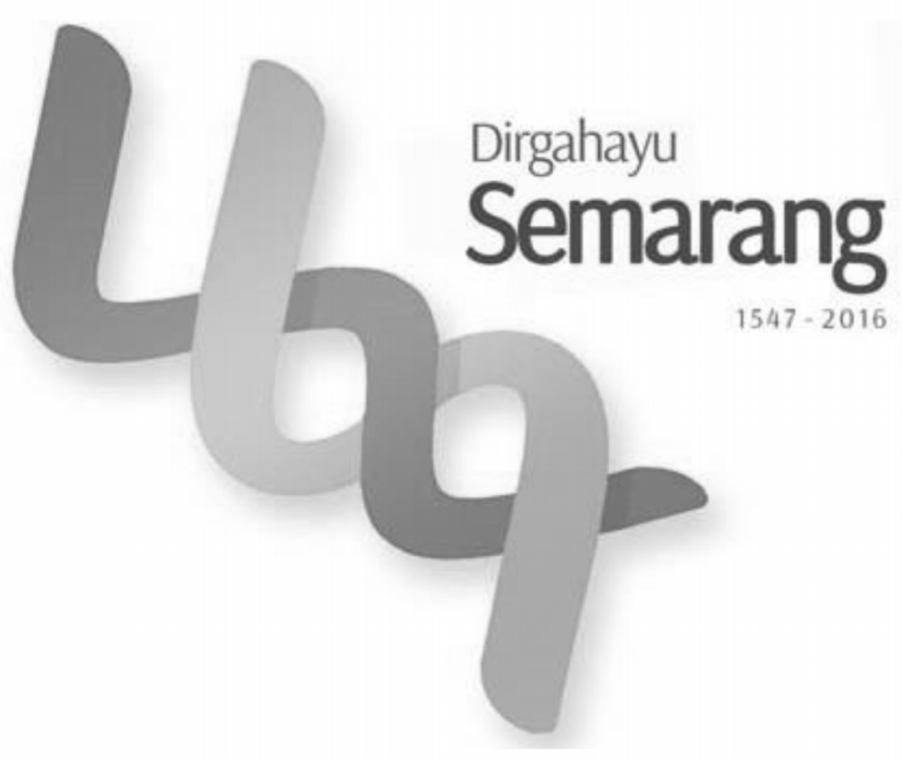

umber: http://beritajateng.net/nih-pemenang-lomba-logo-hut-ke-469-kot: 
Deskripsi singkat mengenai logo tersebut ada empat poin (Tribunenews.com, 2016):

1. angka dibentuk oleh dua buah tali saling mengikat yang bermakna mempererat tali persaudaraan dan silaturahmi seluruh warga Kota Semarang.

2. gradasi tiga warna melambangkan persatuan, tidak membeda-bedakan hak warga.

3. merah melambangkan semangat persatuan yang tak pernah padam, sedangkan kuning melambangkan keharmonisan antar warga.

4. konsep melengkung memberi kesan modern, keren dan inspiratif.

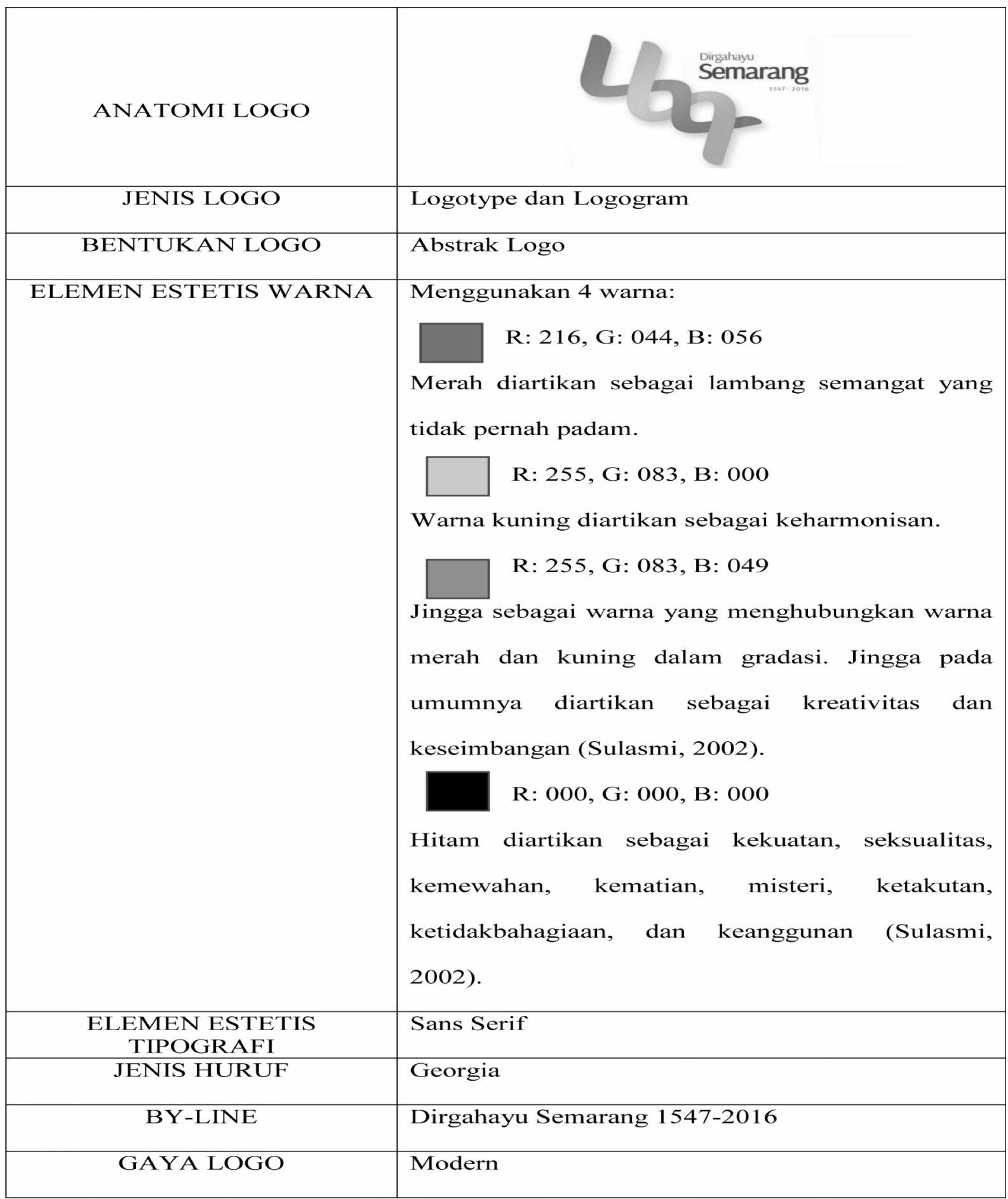


Menurut Hendrar Pihadi, Walikota Semarang, logo hasil karya pemuda berusia 21 tahun ini lebihmeonjol dibandingkan dengan karya peserta lainnya. Angka 469 yang tersembunyi dibalik desain tali yang saling mengikat dengan gradasi warna yang menarik, terlihat sangat sederhana. Hendrar Prihadi juga menyampaikan bahwa logo yang sangat "keren" ini mampu menginspirasi dan meningkatkan semangat masyarakat Kota Semarang, khususnya kaum muda untuk bersama-sama membangun kotanya.

Hendrar Prihadi sangat mengapresiasi logo
HUT Kota Semarang tahun 2016 ini, karena menurutnya usaha pemerintah kota untuk mengajak masyarakat ikut serta dan berperan aktif dalam pembangunan kota tidak bertepuk sebelah tangan. Logo ini juga dinilai mampu merepresentasikan tema HUT Kota Semarang ke 469 yaitu, "Bulatkan Tekad Semarang Hebat". Walikota yang akrab disapa Hendi ini juga berharap pengikutsertaan masyarakat dalam setiap kegiatan Kota Semarang dapat terus dilakukan di tahun-tahun mendatang.

\section{Pembahasan}

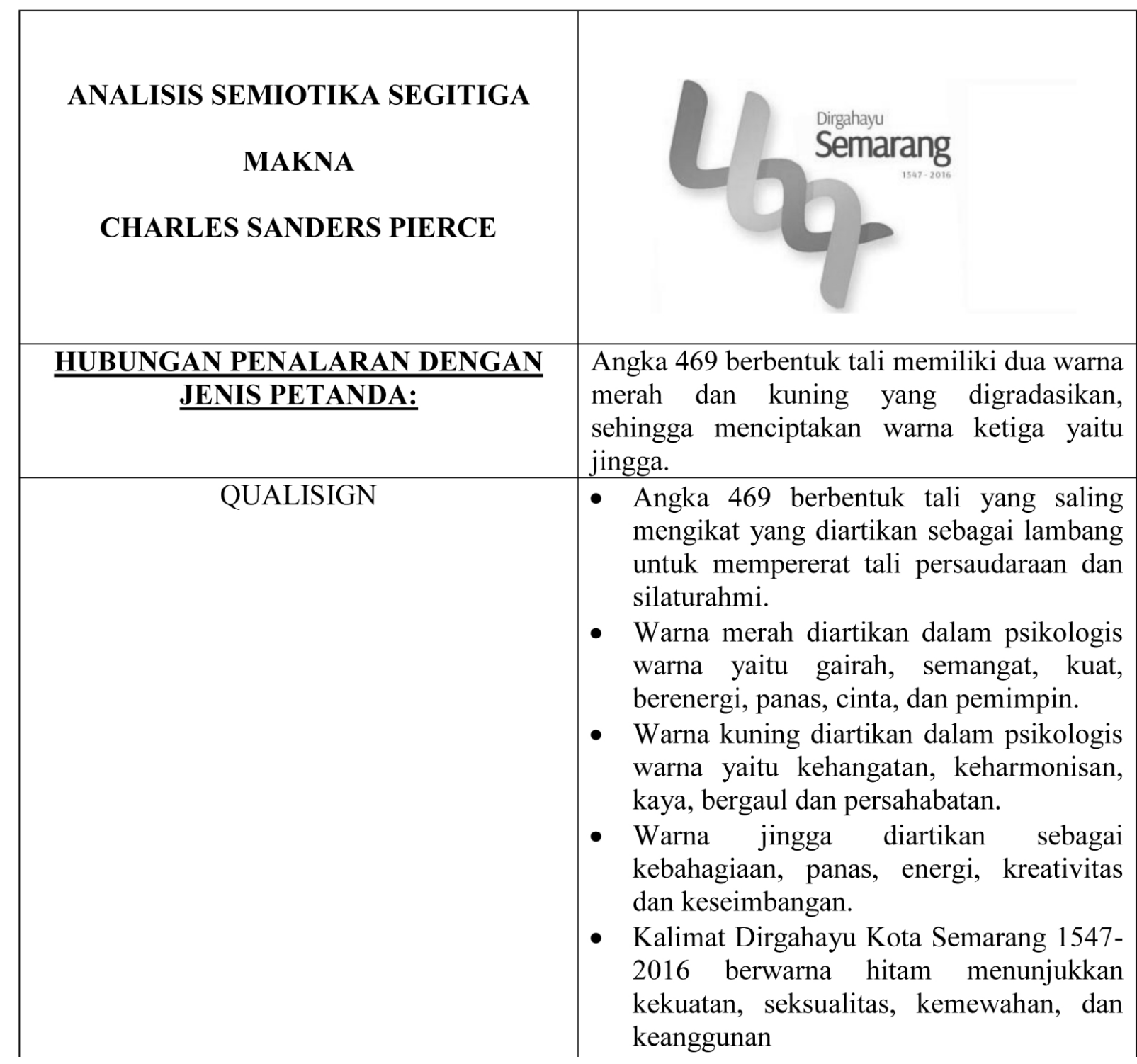




\begin{tabular}{|c|c|}
\hline & $\begin{array}{l}\text { Kata Dirgahayu dan 1547-2016 } \\
\text { dicetak tipis dengan font yang lebih } \\
\text { kecil jika dibandingkan dengan kata } \\
\text { Semarang. Hal ini menunjukkan } \\
\text { bahwa Semarang menjadi fokus utama } \\
\text { dalam design ini. } \\
\text { Kalimat Dirgahayu Semarang 1547-2016 } \\
\text { adalah tipografi yang menggunakan font } \\
\text { Georgia dan merupakan ciri huruf Sans } \\
\text { Serif atau tanpa kait/kaki/ujung. }\end{array}$ \\
\hline \multirow[t]{2}{*}{ SINSIGN } & $\begin{array}{l}\text { - Angka } 469 \text { yang berbentuk seperti dua } \\
\text { buah tali yang saling terkait } \\
\text { mencerminkan kerukunan, ikatan tali } \\
\text { persaudaraan dan keharmonisan. Bentuk } \\
\text { ini mewakili semboyan Kota Semarang } \\
\text { "Bulatkan Tekad, Semarang hebat". } \\
\text { Melalui logo ini dikomunikasikan kepada } \\
\text { masyarakat untuk dapat lebih rukun, } \\
\text { damai dan bersatu dalam mewujudkan } \\
\text { pembangunan menuju Kota Semarang } \\
\text { yang hebat. }\end{array}$ \\
\hline & $\begin{array}{l}\text { - Kalimat Dirgahayu Semarang } 1547-2016 \\
\text { menggunakan tipografi Georgia dan } \\
\text { merupakan ciri dari huruf Sans Serif atau } \\
\text { tanpa ujung/kaki/kait. Sans Serif } \\
\text { disimbolisasikan modernitas, } \\
\text { kontemporer, dan efisien. Dalam tipografi } \\
\text { kata Semarang dicetak lebih tebal } \\
\text { dibandingkan dengan kata Dirgahayu dan } \\
\text { 1547-2016. Hal ini menunjukkan } \\
\text { Semarang sebagai fokus yang diterangkan } \\
\text { oleh logo 469 yang berbentuk tali. } \\
\text { Kalimat Dirgahayu danAngka } 1547-2016 \\
\text { merupakan keterangan yang menunjukkan } \\
\text { usia Kota Semarang pada HUTnya di } \\
\text { tahun 2016. }\end{array}$ \\
\hline LESINSIGN & $\begin{array}{l}\text { Studi ini mengartikan bahwa logo HUT Kota } \\
\text { Semarang ke } 469 \text { yang dilihat oleh } \\
\text { masyarakat diartikan sebagai lambang } \\
\text { keharmonisan warga, kerukunan, } \\
\text { kebahagiaan dan kekuatan kebersamaan yang } \\
\text { menumbuhkan jiwa muda dan moderanisasi } \\
\text { Kota Semarang. Masyarakat juga dituntut } \\
\text { untuk lebih berperan aktif dalam } \\
\text { pembangunan kotanya, terlebih di usia Kota } \\
\text { Semarang yang ke } 469 \text { ini. }\end{array}$ \\
\hline
\end{tabular}




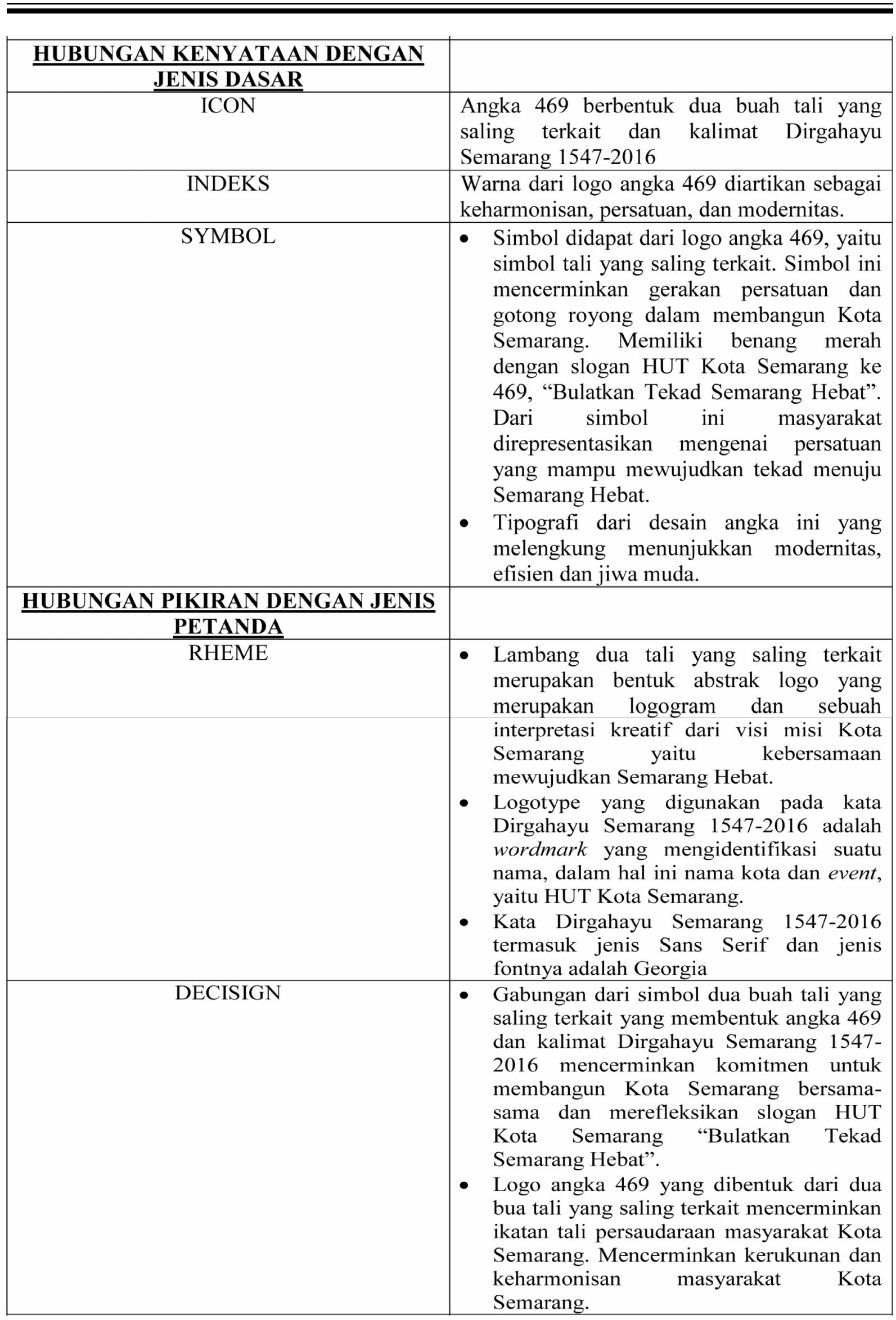


ARGUMENT

Studianalisis terhadap logo merupakan studi yang memaknai logo berdasarkan dengan persepsi yang dicocokkan dengan teori yang ada. Berikut pemaknaan logo HUT Kota Semarang ke 469:

Pertama, secara visual logo HUT Kota Semarang ke 469 memiliki bentuk logo dua buah tali yang saling terkait, elemen estetis pembentuknya merupakan kombinasi dua buah tali yang melengkung membentuk angka 469 . Jenis logonya dalah logogram yang mempresentasikan ikatan tali persaudaraan masyarakat Semarang dalam membangun kotanya. Di sisi lain logotype dilihat dari kalimat Dirgahayu Semarang 1547-2016. Kemudian warna logo pada simbol dua buah tali yang saling terkait memiliki dua warna merah dan kuning yang digradasikan sehingga menciptakan warna ketiga yaitu warna jingga. Dalam kalimat Dirgahayu Semarang 1547-2016 menggunakan warna hitam, kata Semarang dicetak tebal dengan ukuran font lebih besar, sedangkan kata Dirgahayu dan angka 1547-2016 dicetak lebih tipis dan ukuran font lebih kecil.Jenis tipografi kalimat tersebut adalah Sans Serif dengan jenis hurufGeorgia. Keseluruhan dari logo HUT Kota Semarang ke 469 ini adalah model logo yang modern.

Kedua, analisis logo menggunakan analisis semiotika Charles Sanders Peirce logo HUT Kota Semarang. Metode analisis ini, yang pertama membahas hubungan penalaran dengan jenis petandanya yaitu qualisign, logo HUT Kota Semarang ke 469 dilihat dari angka 469 yang oleh dua buah tali yang salin $g$ terkait memiliki
- Logo angka 469 yang dibentuk oleh dua tali yang saling terkait mencerminkan suatu identitas bahwa masyarakat Kota Semarang memiliki ikatan tali persaudaraan yang kuat dalam membangun kotanya.

- Hal ini dapat dilihat dari hasil penelitian yang telah dipaparkan dalam studi semiotika ini.

dua warna merah dan kuning yang digradasikan dan menciptakan warna ketiga yaitu jingga. Warna merah diartikan dalam psikologis warna yaitu gairah, semangat, kuat, berenergi, panas, cinta, dan pemimpin. Warna kuning diartikan dalam psikologis warna yaitu kehangatan, keharmonisan, kaya, bergaul dan persahabatan. Sedangkan warna jingga diartikan sebagai kebahagiaan, panas, energi, kreativitas dan keseimbangan. Di dalam ketiga warna tersebut ditemukan penggambaran visi dan misi Kota Semarang, yaitu persatuan, gotongroyong dalam membangun kota mewujudkan Semarang yang hebat dengan membulatkan tekad bersamasama.

Kalimat Dirgahayu Semarang 1547-2016 memiliki satu warna yaitu hitam. Warna hitam menunjukkan kekuatan, seksualitas, kemewahan, dan keanggunan. Kata Dirgahayu dan angka 1547-2016 dicetak lebih tipis dan fontnya lebih kecil, sedangkan nama kota Semarang dicetak tebal dengan ukuran font yang lebih besar. Namun keseluruhan kalimat menggunakan jenis huruf yang sama yaitu Georgia yang tergolong jenis huruf Sans Serif, yaitu huruf yang tidak memiliki kaki atau ujung dan merupakan simbol modernisasi.

Sinsign, logo HUT Kota Semarang ke 469 yang terbentuk dari dua buah tali yang saling terkait mencerminkan kerukunan, ikatan tali persaudaraan dan keharmonisan. Bentuk ini mewakili semboyan Kota Semarang "Bulatkan Tekad, Semarang hebat". Melalui logo ini dikomunikasikan kepada masyarakat untuk dapat lebih rukun, damai dan bersatu dalam mewujudkan pembangunan menuju Kota 
Semarang yang hebat.

Kalimat Dirgahayu Semarang 1547-2016 menggunakan tipografi Georgia dan merupakan ciri dari huruf Sans Serif atau tanpa ujung/kaki/ kait. Sans Serif disimbolisasikan modernitas, kontemporer, dan efisien. Dalam tipografi kata Semarang dicetak lebih tebal dibandingkan dengan kata Dirgahayu dan 1547-2016. Hal ini menunjukkan Semarang sebagai fokus yang diterangkan oleh logo 469 yang berbentuk tali. Kalimat Dirgahayu dan Angka 1547-2016 merupakan keterangan yang menunjukkan usia Kota Semarang pada HUTnya di tahun 2016.

Legisign, dalam studi analisis logo HUT Kota Semarang ke 469 dilihat sebagai sebuah simbol yang unik, modern, dan menarik untuk dianalisis, karena logo ini tidak dapat secara langsung dipahami bahwa simbol tali yang saling terkait tersebut ternyata membentuk angka 469, di mana angka tersebut merupakan usia Kota Semarang saat ini. Simbol tali yang saling terkait dilihat sebagai sebuah simbol ikatan tali persaudaraan, kebersamaan, kerukunan, keharmonisan, keseimbangan. Hal ini menggambarkan harapan besar pemerintah Kota Semarang untuk bisa mempersatukan masyarakatnya untuk bersama-sama mewujudkan Kota Semarang yang hebat. Simbol tali yang saling terkait dengan warna gradasi juga dipandang sebagai peleburan status sosial, sehingga persatuan dalam pembangunan kota tidak pandang bulu. Setiap lapisan masyarakat diharapkan mau dam mampu bergotong royong. Di sisi lain, simbol ini juga dapat diartikan bahwa baik pemerintah maupun masyarakat melebur menjadi satu untuk kemajuan kota.

Metode analisis segitiga makna Charles Sanders Peirce yang kedua membahas hubungan kenyataan dengan jenis dasarnya atau icon, dilihat dari bentuk logo angka 469 yang terbentuk dari dua buah tali yang saling terkait dan kalimat Dirgahayu Semarang 1547-2016. Indeks, warna dari logo diartikan diartikan sebagai keharmonisan, persatuan, dan modernitas. Warna gradasi juga menunjukkan persatuan yang tidak memandang bulu, meleburkan status-status sosial untuk persatuan. Symbol, didapat dari logo angka 469, yaitu simbol tali yang saling terkait. Simbol ini mencerminkan gerakan persatuan dan gotong royong dalam membangun Kota Semarang. Memiliki benang merah dengan slogan HUT Kota Semarang ke 469, "Bulatkan Tekad Semarang Hebat". Dari simbol ini masyarakat direpresentasikan mengenai persatuan yang mampu mewujudkan tekad menuju Semarang Hebat. Tipografi dari desain angka ini yang melengkung menunjukkan modernitas, efisien dan jiwa muda.

Lengkapnya, metode analisis segitiga makna Charles Sanders Peirce yangketiga membahas hubungan pikiran dengan jenis petandanya, diantaranya Rheme, lambang dua tali yang saling terkait merupakan bentuk abstrak logo yang merupakan logogram dan sebuah interpretasi kreatif dari visi misi Kota Semarang yaitu kebersamaan mewujudkan Semarang Hebat. Logotype yang digunakan pada kata Dirgahayu Semarang 1547-2016 adalah wordmark yang mengidentifikasi suatu nama, dalam hal ini nama kota dan event, yaitu HUT Kota Semarang. Kata Semarang yang dicetak lebih tebal dengan ukuran yang lebih besar menunjukkan bahwa Semarang menjadi fokus dari logo tali yang saling mengikat tersebut. Hal ini juga merupakan alasan logo angka 469 ini digunakan di setiap kegiatan Kota Semarang selama satu tahun ke depan, tidak hanya ketika merayakan hari ulang tahun Kota Semarang saja. Kata Dirgahayu Semarang 1547-2016 termasuk jenis Sans Serif dan jenis fontnya adalah Georgia.

Decisign, Gabungan dari simbol dua buah tali yang saling terkait yang membentuk angka 469 dan kalimat Dirgahayu Semarang 15472016 mencerminkan komitmen untuk membangun Kota Semarang bersama-sama dan merefleksikan slogan HUT Kota Semarang 
"Bulatkan Tekad Semarang Hebat". Logo angka 469 yang dibentuk dari dua bua tali yang saling terkait mencerminkan ikatan tali persaudaraan masyarakat Kota Semarang. Mencerminkan kerukunan dan keharmonisan masyarakat Kota Semarang.

Argument, logo angka 469 yang dibentuk oleh dua tali yang saling terkait mencerminkan suatu identitas bahwa masyarakat Kota Semarang memiliki ikatan tali persaudaraan yang kuat dalam membangun kotanya. Bentuk angka yang melengkung juga mencerminkan modernisasi, sehingga melalui logo ini Pemerintah Kota Semarang berharap kaum muda di Semarang pada khususnya ikut berperan serta dan aktif dalam membangun Kota Semarang.

Berdasar hasil penelitian yang telah dijabarkan di atas, dapat diketahui bahwa melalui semiotika dapat diketahui lebih banyak informasi tentang beberapa faktor krusial dalam desain, namun tidak dipungkiri bahwa aplikasi semiotika masih membutuhkan dukungan dari bidangbidang ilmu lain yang mengapresiasi pelbagai kualitas desain itu sendiri.

\section{PENUTUP}

\section{Simpulan}

Pemerintah Kota Semarang mengajak masyarakatnya untuk ikut berperan aktif dalam pembangunan kota melalui lomba pembuatan logo HUT Kota Semarang ke 469. Hasil karya Ibnu Pramudya, pemuda berusia 21 tahun asal kabupaten Kendal keluar sebagai pemenang, dipilih langsung oleh Walikota Semarang, Hendrar Prihadi. Logo dengan angka 469 yang terbentuk dari dua buah tali yang saling terkait dengan warna gradasi merah dan kuning dinilai mampu mencerminkan semangat persatuan, melambangkan ikatan tali persaudaraan dan keharmonisan. Logo ini dinilai juga sesuai dengan tema HUT Kota Semarang ke 469, "Bulatkan
Tekad Semarang Hebat".

Menggunakan semiotika segitiga makna (triangel meaning) Charles Sanders Peirce, logo ini dianalisis berdasarkan pada tanda, penggunaan tanda, dan interpretan. Hubungan antara penalaran dan tanda menunjukkan bahwa logo angka 469 dan simbol dua buah tali yang saling terkait merefleksikan ikatan tali persaudaran yang erat. Sedangkan warna merah dan kuning yang digradasikan sehingga menciptakan warna ketiga yaitu jingga secara psikologis warna diartikan kehangatan, keharmonisan, kreativitas. Dan warna hitam pada tulisan Dirgahayu Semarang 1547-2016 yang berwarna hitam diartikan sebagai kekuatan dan kemewahan. Logo dilihat dari hubungan kenyataan dengan jenis dasarnya, bentuk logo yang memiliki banyak lengkungan dalam keterkaitan dua tali tersebut melambangkan persatuan yang erat, efektif dan modern. Di sisi lain logo dilihat dari hubungan antara penalaran dengan jenis petanda, simbol tali yang membentuk angka 469 merupakan logogram yang mencerminkan persatuan, sedangkan tulisan Dirgahayu Semarang 1547-2016 merupakan logotype yang menggunakan jenis huruf sans serif yaitu huruf yang tidak berujung atau tidak berkaki, jenis fontnya adalah Georgia. Semarang yang dicetak lebih tebal dan ukuran font lebih besar menggambarkan bahwa Semarang adalah fokus yang dijelaskan oleh logo 469 tersebut. Keseluruhan elemen logo HUT Kota Semarang ke 469 ini adalah cerminan visi misi Kota Semarang, membentuk persatuan yang harmonis dalam mewujudkan tekad yang bulat menuju Semarang hebat.

Berdasar pada analisis semiotika segitiga makna Charles Sanders Peirce, ditemui hasil bahwa logo hasil karya Ibnu Pramudya pemenang Lomba Logo HUT Kota Semarang ke 469 mampu memenuhi syarat yang diajukan oleh dewan juri. Logo dengan bentuk jalinan angka 4, 6, dan 9 dari dua buah tali yang saling terkait dengan gradasi warna merah dan kuning 
ini, mampu mencerminkan visi dan misi serta jati diri Kota Semarang, terlebih pada momen hari jadinya yang ke 469 yang mengambil tema "Bulatkan Tekad, Semarang Hebat". Hal ini tidak hanya dimaknai secara mandiri oleh pencipta logo, tetapi juga dapat menyampaikan pesan yang sama kepada penafsir lainnya, seperti halnya dewan juri dan masyarakat Kota Semarang pada umumnya.

\section{Saran}

Tidak dipungkiri bahwa sebuah logo dapat dimaknai berbeda bergantung dari sudut pandang interpretan dan proses pemahaman logo itu sendiri. Tidak sedikit masyarakat yang awalnya merasa bingung dan tidak memahami bentuk logo 469 yang melengkung seperti jalinan tali ini. Berdasar pada hal tersebut, pencipta logo diharap untuk lebih mampu menciptakan logo yang ramah pandang dan mudah dipahami oleh masyarakat awam pada umumnya. Penciptaan logo untuk HUT Kota Semarang, di mana logo ini akan digunakan untuk setiap perhelatan yang diadakan Pemerintah Kota, diharap lebih mengedepankan elemen-elemen dasar yang mencerminkan visi dan misi sekaligus jati diri Kota Semarang, sehingga pesan yang disampaikan melalui logo dapat lebih mudah dipahami dan memperoleh kesamaan makna antara pencipta dan intepretan.

Berdasar pada hasil analisis semiotika menggunakan segitiga makna Charles Sanders Peirce, penelitian selanjutnyadapat menganalisis logo HUT Kota Semarang ke 469 menggunakan analisis semiotika tokoh-tokoh yang lain, sehingga dapat ditemukan persamaan maupun perbedaan pandangan makna dari logo yang dinilai unik dan menarik, hasil karya dari Ibnu Pramudya pemenang Lomba Logo HUT Kota Semarang ke 469.

\section{DAFTAR RUJUKAN}

Budiman, Kris. (2011). Semiotika Visual. Yogyakarta: Jalasutra Anggota IKAPI.

Kusrianto, Adi. (2009)z. Pengantar Desain Komunikasi Visual. Yogyakarta: ANDI.

Sobur, Alex. (2004). Semiotika Komunikasi. Bandung: Remaja Rosdakarya. . (2003). Semiotika Komunikasi. Bandung: Remaja Rosdakarya. . (2013). Semiotika Komunikasi. Bandung: Remaja Rosdakarya. (2009). Analisis Teks Media.Bandung: Remaja Rosdakarya.

Suwardikun, Didit W. (2000). Merubah Citra Melalui Perubahan Logo. Bandung: ITB Library.

Tinarbuko, Sumbo. (2009). Semiotika Komunikasi Visual: Edisi Revisi (Cetakan Ketiga). Yogyakarta: Jalasutra Anggota IKAPI.

Vihma, Susann \& Vakeva, Seppo. (2009). Semiotika Visualdan Semantika Produk. Yogyakarta \& Bandung: Jalasutra.

West, Richard and Turner, Lynn H. (2009). Teori Komunikasi. Jakarta: Salemba Humanika.

Banjir Kemeriahan di HUT Ke-469 Kota Semarang. (2016). 
http://berita.suaramerdeka.com/smcetak/banjir-kemeriahan-di-hut-ke-469-kota-semarang. Diakses pada 19 September 2016.

Ellya. (2016). Yuk Ikut Lomba Desain Logo HUT Kota Semarang ke- 469.

http://beritajateng.net/yuk-ikut-lomba-desain-logo-hut-kota-semarang-ke-469. Diakses pada 18 September 2016.

Ini Logo HUT Kota Semarang ke-469. (2016).

http://tabloidsimpang5.com/ini-logo-hut-kota-semarang-ke-469. Diakses pada 23 September 2016.

Mohammad, Razhiza BT. (2009). Kreativiti dan Seni Tampak Kanak-Kanak. https:// www.scribd.com/doc/18580294/Komunikasi-Visual. Diakses pada 24 September 2016.

Napoles, Veronica. (1998). Corporate Identity Design. New York: Van Nostrand Reinhold.

Sari, Lukita. (2011). Analisis Semiotika Logo Ades. http://itkp.ac.id/file/ 1Analisis\%20Semiotika\%20Logo\%20Ades\%202011\%20da\%202012.pdf. Diakses pada 10 Oktober 2016. 